\title{
An examination of the effects of different doses of recombinant human growth hormone on children with growth hormone deficiency
}

\author{
YING XUE, YIQING GAO, SHUQIN WANG and PEI WANG \\ Department of Endocrinology, Xuzhou Children's Hospital, Xuzhou, Jiangsu 221002, P.R. China
}

Received June 26, 2015; Accepted February 19, 2016

DOI: $10.3892 /$ etm.2016.3091

\begin{abstract}
The aim of the present study was to examine the effects of different doses of recombinant human growth hormone (rhGH) on children with growth hormone deficiency (GHD) and on thyroid and glucose metabolism to identify more reasonable therapeutic doses of growth hormone $(\mathrm{GH})$ for the treatment of this condition. In total, 60 prepubertal patients with GHD were randomly divided into the high-dose and low-dose groups ( $n=30$ per group). The groups were treated with 0.1 or $0.05 \mathrm{U} / \mathrm{kg}$ for 6 months, respectively. The follow-up study focused on changes to the serum levels of insulin-like growth factor-1 (IGF-1), insulin-like growth factor binding protein (IGFBP)-3, blood glucose, thyroid hormone [triiodothyronine (T3) and its prohormone, thyroxine (T4), and thyroid stimulating hormone (TSH)] and the analysis of variance of the repeated data. Changes in the height, body weight and bone age of the high-dose group were greater than those of the low-dose group. After 6 months of treatment, the difference in height between the two groups was statistically significant $(\mathrm{P}<0.05)$. Glucose metabolism in the two groups was consistent, but there was a statistically significant difference in the fasting blood glucose (FBG) levels of the two groups after 6 months of treatment $(\mathrm{P}<0.05)$. Prior to treatment, the T3, T4 and TSH values (the thyroid function tests) in the two groups, especially for the value of T3 in high-dose group were varied. However, 6 months after treatment, statistically significant differences between the two groups $(\mathrm{P}<0.05)$ were identified. In conclusion, $0.1 \mathrm{U} / \mathrm{kg}$ of $\mathrm{GH}$ is beneficial to children with GHD in attaining a satisfactory height, but it leads to insulin resistance. Thus, glucose metabolism and thyroid function should be monitored on a regular basis in a clinical setting.
\end{abstract}

Correspondence to: Dr Ying Xue, Department of Endocrinology, Xuzhou Children's Hospital, 18 Sudibei Road, Xuzhou, Jiangsu 221002, P.R. China

E-mail: xueying96@yeah.net

Key words: growth hormone deficiency, recombinant human growth hormone, growth pattern, thyroid, glucose metabolism

\section{Introduction}

Growth hormone deficiency (GHD) is a type of growth disorder which is caused by growth hormone (GH) deficiency or inadequate secretion of $\mathrm{GH}$ due to hypothalamus or anterior pituitary dysfunction $(1,2)$. It is a common disorder of the endocrine system in children. The pituitary growth hormone secretion is stimulated by growth hormone-releasing hormone from the hypothalamus and possibly by another signal that may be stimulated by growth hormone-releasing peptides. Its deficiency can result from disruption of the growth hormone axis in the higher brain, hypothalamus or pituitary gland.

The frequency of isolated growth hormone deficiency has been reported to range from 1 case per 1,800 children in Sri Lanka (a probable overestimate due to liberal diagnostic criteria) to 1 case per 30,000 children in Newcastle, UK (a probable underestimate due to its reliance on referral rates to a growth clinic) $(3,4)$. Although no ethnic difference in the incidence of growth hormone deficiency is apparent, the rate at which patients receive growth hormone therapy appears to differ. From $\sim 9,000$ patients with idiopathic growth hormone deficiency in a large North American database of patients treated with growth hormone, $85 \%$ were of Caucasian descent, $6 \%$ were of Afican-American descent, and $2 \%$ were of Asian descent (5-7). Children with growth hormone deficiency are usually much shorter than their peers, at below the 3rd percentile line, and over time, their height decreases to below the normal range. Diagnosis cannot be made by a single level as it is secreted in pulses. Another diagnostic method is the growth hormone stimulation test although this can lead to overdiagnosing the deficiency. Usually, other tests including $\mathrm{X}$ rays and $\mathrm{CT}$ scans are used to check the pituitary gland or to evaluate the brain (MRI) are performed when treatment is considered (8).

Various treatments are available for this disorder. Recombinant human growth hormone (rhGH) is the most widely used treatment (9). It was previously shown (10) that the drug has satisfactory results, but the safety of hormone replacement therapy remains controversial. Current practise involves daily subcutaneous injections of the recombinant hormone.

In the present study, the various parameters which influence the growth curve of the child were considered. The study 
Table I. Comparison of height, weight, HV, HtSDS and BA between the two groups (the means \pm SD).

\begin{tabular}{|c|c|c|c|c|c|c|c|}
\hline Group & Treatment & Time & Height (cm) & Weight (kg) & $\mathrm{HV}$ (cm/year) & HtSDS & BA \\
\hline \multirow[t]{4}{*}{$\begin{array}{l}\text { High-dose } \\
\text { group }\end{array}$} & $\begin{array}{l}\text { Before } \\
\text { treatment }\end{array}$ & & $125.39 \pm 6.76$ & $27.84 \pm 6.02$ & $3.37 \pm 0.18$ & $-2.66 \pm 0.15$ & $5.87 \pm 0.69$ \\
\hline & $\begin{array}{l}\text { After } \\
\text { treatment }\end{array}$ & 1 month & $135.93 \pm 6.70^{\mathrm{a}}$ & $35.06 \pm 5.93^{\mathrm{a}}$ & $16.95 \pm 6.47^{\mathrm{a}}$ & $-1.85 \pm 0.63^{\mathrm{a}}$ & $6.33 \pm 3.18^{\mathrm{a}}$ \\
\hline & & 3 months & $140.89 \pm 6.58^{\mathrm{a}, \mathrm{b}}$ & $37.46 \pm 5.49^{a}$ & $11.18 \pm 4.85^{\mathrm{a}, \mathrm{b}}$ & $-1.77 \pm 0.52^{\mathrm{a}}$ & $6.98 \pm 4.81^{\mathrm{a}, \mathrm{b}}$ \\
\hline & & 6 months & $148.04 \pm 6.46^{\mathrm{a}-\mathrm{c}}$ & $37.05 \pm 5.41^{\mathrm{a}}$ & $12.05 \pm 5.84^{\mathrm{a}, \mathrm{b}}$ & $-1.69 \pm 0.37^{\mathrm{a}, \mathrm{c}}$ & $7.17 \pm 0.81^{\mathrm{a}, \mathrm{b}}$ \\
\hline \multirow[t]{4}{*}{$\begin{array}{l}\text { Low-dose } \\
\text { group }\end{array}$} & $\begin{array}{l}\text { Before } \\
\text { treatment }\end{array}$ & & $126.25 \pm 14.88$ & $26.84 \pm 6.31$ & $3.41 \pm 1.06$ & $-2.64 \pm 1.41$ & $5.91 \pm 3.74$ \\
\hline & $\begin{array}{l}\text { After } \\
\text { treatment }\end{array}$ & 1 month & $130.41 \pm 16.52^{\mathrm{d}}$ & $30.54 \pm 7.95^{\mathrm{d}}$ & $12.51 \pm 6.41^{\mathrm{a}, \mathrm{d}}$ & $-2.06 \pm 4.15^{\mathrm{a}, \mathrm{d}}$ & $6.22 \pm 2.73^{d}$ \\
\hline & & 3 months & $138.64 \pm 45.18^{\mathrm{a}, \mathrm{b}}$ & $35.54 \pm 11.25^{\mathrm{a}, \mathrm{b}}$ & $10.95 \pm 6.32^{\mathrm{a}}$ & $-1.68 \pm 0.95^{\mathrm{a}, \mathrm{b}, \mathrm{d}}$ & $6.81 \pm 1.98^{\mathrm{a}, \mathrm{b}, \mathrm{d}}$ \\
\hline & & 6 months & $142.51 \pm 36.95^{\mathrm{a}-\mathrm{d}}$ & $35.78 \pm 16.24^{\mathrm{a}, \mathrm{b}}$ & $10.96 \pm 4.87^{\mathrm{a}, \mathrm{d}}$ & $-1.70 \pm 0.21^{\mathrm{a}, \mathrm{b}}$ & $6.99 \pm 4.02^{\mathrm{a}, \mathrm{b}}$ \\
\hline
\end{tabular}

Comparison between the two groups as well as comparison in between each group. Comparison before treatment and after treatment for low-dose treatment group, ${ }^{\mathrm{a}} \mathrm{P}<0.05$; after 1 month after treatment, ${ }^{\mathrm{b}} \mathrm{P}<0.05$; after 3 months of treatment, ${ }^{\mathrm{c}} \mathrm{P}<0.05$; after 6 months of treatment. Comparison before and after treatment for the same period as the high-dose group at 1 month, 3 months and 6 months, ${ }^{\mathrm{d}} \mathrm{P}<0.05$. HV, growth rate curve (height velocity); HtSDS, height standard deviation score; BA, bone age.

analyzes the linear growth and metabolism changes of GHD which were treated with different doses of rhGH.

\section{Subjects and methods}

Subjects. The study was conducted on 60 prepubertal patients with GHD, all of whom fulfilled GH deficiency diagnostic criteria, as previously described (11). Of the 60 patients, there were 39 males and 21 females, with ages ranging from 4 to 9 years and bone ages ranging from 3.5 to 7.5 years old. In 27 cases, there was a complete lack of GH (serum GH peak value was $<5 \mu \mathrm{g} / 1$ in the $\mathrm{GH}$-stimulation test), and 33 cases had a milder form of GH deficiency (serum GH peak value was between 5 and $8 \mu \mathrm{g} / 1$ in the $\mathrm{GH}$ stimulation test). The two groups were demographically matched and there was no statistically significant difference in age, gender ratio, $\mathrm{GH}$-stimulation test results or fasting blood glucose (FBG) levels between the two groups $(\mathrm{P}>0.05)$. The study was conducted according to the requirements of the Declaration of Helsinki and Nuremberg Code. The study protocol was approved by the Ethics Committee of Xuzhou Children's Hospital (Xuzhou, China), and consent was provided by the parents or guardians of all patients.

Methods. rhGH therapy was used as treatment in all the cases. Treatment was undertaken in the outpatient department, and rhGH (Zhuhai Hengtong Bio-Pharmaceutical Co., Zhuhai, China) was used as treatment. The high-dose and low-dose groups were injected daily with 0.1 or $0.05 \mathrm{U} / \mathrm{kg}$, respectively. The method of delivery was a subcutaneous injection $1 \mathrm{~h}$ prior to sleep, 6 days a week. The injection was administered by properly trained staff. Follow-up visits were conducted 1, 3 and 6 months following treatment to monitor the indicators such as height, weight, FBG, area under blood glucose curve (AUCglu), insulin-like growth factor-1 (IGF-1), insulin-like growth factor binding protein (IGFBP)-3, thyroid hormone functions [triiodothyronine (T3) and its prohormone, thyroxine
(T4) and thyroid stimulating hormone (TSH)] and bone age. The growth rate curve (height velocity of gain in $\mathrm{cm}$; HV) and height standard deviation score (HtSDS) points were also examined. To avoid differences between batches, the samples were measured three times, consecutively, and the mean values were recorded. Enzyme-linked immunosorbent assay (ELISA) was used to measure serum hormone levels. Height, weight and AUCglu were measured according to standard guidelines (12).

Statistical methods. Data were analyzed using the software package SPPS 20.0 and presented as means \pm SD. The Kolmogorov-Smirnov normality test was performed, followed by analysis of the two doses that met the normal distribution. The Mauchly spherical symmetry distribution test was used for the repeated measurement of analysis of variance. The Bonferroni correction method was used to compare the data. For data not classed as normal distribution, the Friedman rank sum test was used. The level of significance was $\alpha=0.05$. $\mathrm{P}<0.05$ was considered to indicate a statistically significant difference.

\section{Results}

Changes to height, body weight and bone age. Height, body weight and bone age between the two groups were compared, and the results were statistically significant seen clinically ( $\mathrm{F}=71.651,19.548,31.266,41.154,29.253$; $\mathrm{P}<0.05$; data not shown). After treatment, there was an obvious increase in the height, weight, HV, HtSDS and bone age in the two groups. One month after treatment, the differences between indicators in the high-dose group were statistically significant $(\mathrm{P}<0.05)$, and in the low-dose group the differences of HV and HtSDS in the low-dose group were statistically significant $(\mathrm{P}<0.05)$, as compared to the indicators prior to treatment. Three months after treatment, the differences in height, weight and bone age were statistically significant $(\mathrm{P}<0.05)$, and 6 months after treatment, the difference in height between the two groups was 
Table II. Comparison of FBG, AUCglu, IGF-1 and IGFBP-3 levels between the two groups (the means \pm SD).

\begin{tabular}{|c|c|c|c|c|c|c|}
\hline Group & Treatment & Time & $\mathrm{FBG}(\mathrm{mmol} / \mathrm{l})$ & AUCglu & IGF-1 (ng/ml) & IGFBP-3 $(\mu \mathrm{g} / \mathrm{ml})$ \\
\hline \multirow[t]{4}{*}{$\begin{array}{l}\text { High-dose } \\
\text { group }\end{array}$} & $\begin{array}{l}\text { Before } \\
\text { treatment }\end{array}$ & & $4.50 \pm 1.84$ & $621.25 \pm 34.62$ & $259.42 \pm 126.31$ & $4.06 \pm 7.22$ \\
\hline & $\begin{array}{l}\text { After } \\
\text { treatment }\end{array}$ & 1 month & $4.61 \pm 1.26$ & $652.15 \pm 29.84$ & $295.72 \pm 90.43^{\mathrm{a}}$ & $4.03 \pm 1.01$ \\
\hline & & 3 months & $4.81 \pm 3.91^{\mathrm{a}, \mathrm{b}}$ & $690.14 \pm 102.52$ & $297.33 \pm 106.35^{\mathrm{a}}$ & $4.96 \pm 5.66^{\mathrm{a}, \mathrm{b}}$ \\
\hline & & 6 months & $5.03 \pm 2.95^{\mathrm{a}, \mathrm{b}}$ & $721.25 \pm 36.95$ & $298.15 \pm 96.54^{\mathrm{a}}$ & $5.01 \pm 4.15^{\mathrm{a}, \mathrm{b}}$ \\
\hline \multirow[t]{4}{*}{$\begin{array}{l}\text { Low-dose } \\
\text { group }\end{array}$} & $\begin{array}{l}\text { Before } \\
\text { treatment }\end{array}$ & & $4.52 \pm 1.84$ & $629.87 \pm 64.59$ & $249.58 \pm 116.68$ & $4.10 \pm 0.85$ \\
\hline & $\begin{array}{l}\text { After } \\
\text { treatment }\end{array}$ & 1 month & $4.59 \pm 2.12$ & $666.55 \pm 47.95$ & $271.51 \pm 146.51^{\mathrm{a}}$ & $4.09 \pm 1.62$ \\
\hline & & 3 months & $4.72 \pm 1.95^{\mathrm{a}, \mathrm{b}}$ & $671.15 \pm 68.45$ & $281.19 \pm 95.41^{\mathrm{a}, \mathrm{d}}$ & $4.89 \pm 3.19^{\mathrm{a}, \mathrm{b}}$ \\
\hline & & 6 months & $4.77 \pm 1.11^{\mathrm{a}, \mathrm{b}, \mathrm{d}}$ & $703.21 \pm 85.21$ & $290.68 \pm 81.6^{\mathrm{a}, \mathrm{b}}$ & $4.93 \pm 0.95^{\mathrm{a}, \mathrm{b}}$ \\
\hline
\end{tabular}

Comparison before treatment, ${ }^{\mathrm{a}} \mathrm{P}<0.05$; comparison after 1 month after treatment, ${ }^{\mathrm{b}} \mathrm{P}<0.05$; comparison after 3 months after treatment, ${ }^{\mathrm{c}} \mathrm{P}<0.05$; comparison after 6 months of treatment with high-dose group, ${ }^{\mathrm{d}} \mathrm{P}<0.05$. FBG, fasting blood glucose; AUCglu, area under blood glucose curve; IGF-1, insulin-like growth factor-1; IGFBP-3, insulin-like growth factor binding protein-3.

Table III. Comparison of T3, T4 and TSH between the two groups (the means \pm SD).

\begin{tabular}{|c|c|c|c|c|c|}
\hline Group & Treatment & Time & $\mathrm{T} 3(\mathrm{pmol} / \mathrm{l})$ & $\mathrm{T} 4(\mathrm{pmol} / \mathrm{l})$ & TSH (mIU/l) \\
\hline \multirow[t]{4}{*}{$\begin{array}{l}\text { High-dose } \\
\text { group }\end{array}$} & $\begin{array}{l}\text { Before } \\
\text { treatment }\end{array}$ & & $1.11 \pm 0.25$ & $81.22 \pm 25.47$ & $3.92 \pm 0.76$ \\
\hline & $\begin{array}{l}\text { After } \\
\text { treatment }\end{array}$ & 1 month & $1.19 \pm 0.22^{\mathrm{a}}$ & $69.42 \pm 19.93^{\mathrm{a}}$ & $4.01 \pm 0.68$ \\
\hline & & 3 months & $1.23 \pm 0.22^{\mathrm{a}}$ & $73.55 \pm 19.54^{a}$ & $4.03 \pm 0.87$ \\
\hline & & 6 months & $1.37 \pm 0.65^{\mathrm{a}-\mathrm{c}}$ & $74.51 \pm 26.15^{\mathrm{a}}$ & $2.64 \pm 3.41^{\mathrm{a}-\mathrm{c}}$ \\
\hline \multirow[t]{4}{*}{$\begin{array}{l}\text { Low-dose } \\
\text { group }\end{array}$} & $\begin{array}{l}\text { Before } \\
\text { treatment }\end{array}$ & & $1.13 \pm 0.98$ & $79.51 \pm 31.03$ & $4.01 \pm 0.37$ \\
\hline & $\begin{array}{l}\text { After } \\
\text { treatment }\end{array}$ & 1 month & $1.15 \pm 0.65$ & $71.15 \pm 26.84^{\mathrm{a}}$ & $3.91 \pm 0.61$ \\
\hline & & 3 months & $1.19 \pm 0.31^{\mathrm{a}}$ & $75.74 \pm 19.58$ & $4.06 \pm 1.08$ \\
\hline & & 6 months & $1.26 \pm 1.01^{\mathrm{a}-\mathrm{c}}$ & $74.33 \pm 54.15$ & $3.99 \pm 0.71^{\mathrm{d}}$ \\
\hline
\end{tabular}

Comparison before treatment, ${ }^{\mathrm{a}} \mathrm{P}<0.05$; comparison after 1 month of treatment, ${ }^{\mathrm{b}} \mathrm{P}<0.05$; comparison after 3 months of treatment, ${ }^{\mathrm{c}} \mathrm{P}<0.05$; comparison in the same period with high-dose group, ${ }^{\mathrm{d}} \mathrm{P}<0.05$. TSH, thyroid stimulating hormone; $\mathrm{T} 3$, triiodothyronine; $\mathrm{T} 4$, thyroxine.

statistically significant $(\mathrm{P}<0.05)$. Comparison of height, weight, $\mathrm{HV}, \mathrm{HtSDS}$ and bone age for the two groups is shown in Table I.

Comparison of glucose, AUCglu, IGF-1 and IGFBP-3 between the two groups. The differences in FBG, IGF-1 and IGFBP-3 levels between the two groups were statistically significant ( $\mathrm{F}=41.512$, 26. 412, 21. 051; $\mathrm{P}<0.05$; data not shown). The difference of IGF-1, prior to and after 1 month of treatment was statistically significant $(\mathrm{P}<0.05)$. The differences in $\mathrm{FBG}$ and IGFBP-3 before, and 3 months after, treatment were also statistically significant $(\mathrm{P}<0.05)$. For the FBG levels, the difference between the initial value and that after 6 months of treatment between the two groups was statistically significant $(\mathrm{P}<0.05)$. Three months after the treatment, the difference of IGF-1 between the two groups was statistically significant $(\mathrm{P}<0.05)$.
There was no statistically significant difference between AUCglu levels before and after treatment $(\mathrm{P}>0.05)$ (Table II).

Differences in T3, T4 and TSH between the two groups. The differences in T3, T4 and TSH levels between the two groups were statistically significant $(\mathrm{F}=36.458,19.845,9.255 ; \mathrm{P}<0.05$; data not shown). In the high-dose group, the difference in $\mathrm{T} 3$ and T4 levels before treatment and 1 month after treatment was statistically significant $(\mathrm{P}<0.05)$, and the difference of pretreated TSH and TSH in TSH levels prior to and 6 months after treatment was statistically significant $(\mathrm{P}<0.05)$. In the low-dose group, when the level of T3 prior to treatment was compared to T3 3 months following treatment, the difference was clearly statistically significant $(\mathrm{P}<0.05)$. The difference between $\mathrm{T} 4$ levels prior to and 1 month after treatment was 
statistically significant $(\mathrm{P}<0.05)$, whereas 3 months after treatment T4 levels increased again, and the difference was not statistically significant $(\mathrm{P}>0.05)$. Concerning TSH prior to and after treatment, the difference was not statistically significant ( $P>0.05)$, whereas 6 months after treatment, the difference in the levels of T3 and TSH, as compared with the levels prior to treatment, were statistically significant $(\mathrm{P}<0.05)$ (Table III).

Adverse effects. There were 4 cases of injection reactions on the skin in the high-dose group, and 5 cases in the low-dose group (data not shown). During the treatment, no instances of severe hypothyroidism, systemic allergy, increased intracranial pressure, scoliosis or other adverse reactions in either group of patients were identified.

\section{Discussion}

Previous findings have shown that the effect of rhGH is closely associated with the dosage (13). According to the Growth Hormone Research Institute, for GHD patients, the recommended dose of rhGH was between 0.025 and $0.050 \mathrm{U} / \mathrm{kg}$ (14). In clinical settings, in order to realize the maximum catch-up growth, an increasing dose of an increasing amount was often taken into consideration. Kalina-Faska et al (15) conducted a study in which 32 prepubertal children were treated with high-dose GH therapy $(0.1 \mathrm{U} / \mathrm{kg} ; 0.7 \mathrm{U} / \mathrm{kg} /$ week $)$, consisting of injection therapy twice daily and in the follow-up visits, the treatment was found to be safe. However, due to the differences in rhythm and dose between the exogenous GH supplement and the body's secretion, concerns regarding the possible adverse reactions remain. The results of an open, multi-center clinical monitoring study, conducted during the period 1985-2006, by the GH Research Society NCGS (16) with a sample number of 54,996 (65\% males and 35\% females), showed that although the majority of deaths had an indirect causal association with the administration of $\mathrm{rhGH}$, the long-term use of high doses of rhGH in children may increase the risks of diabetes, pancreatitis, renal insufficiency, and intracranial hypertension. Ranke et al (17) suggested rhGH may increase the burden of thyroid, leading to the 'hidden' thyroid hypothyroidism becoming 'dominant'. Recent studies have also indicated that the rate of pancreatitis increased following treatment with rhGH in children, particularly in children with diabetes, pseudohypoparathyroidism or those undergoing glucocorticoid therapy. Thus, when rhGH is used as a treatment, we should be vigilant to the risk of pancreatitis. In previous examinations, it was identified that $0.1 \mathrm{U} / \mathrm{kg}$ of $\mathrm{GH}$ effectively result in catch-up growth in children and reduce the incidence of adverse reactions at the same time (16-20).

We suggest that rhGH in the body stimulates the liver to produce IGF-1 and IGF-2. IGF-1, which promotes cell growth and differentiation, has a wide range of biological effects. IGFBP had high affinity to IGF, which prolonged the half-life of IGF and aided in the inhibition of IGF and transporting of the plasma. Studies have shown that IGF-1 and IGFBP-3 were the most important growth regulators during the growth and development period of children. Rose et al (21) found that IGF-1 and IGFBP-3 levels in children with GHD were significantly lower than children unaffected by GHD. However, after supplementary exogenous GH, IGF-1 and IGFBP-3 were administered, this changed and there was a linear correlation between IGF-1 and IGFBP-3 and the growth rate. The results of the present study show that following treatment, growth in relation to height and a significant improvement in $\mathrm{HV}$ and HtSDS were evident in the two groups. Notably, the growthpromoting effect was most pronounced at 1 month of treatment in the high-dose group and 3 months of treatment in the lowdose group $(\mathrm{P}<0.05)$. Additionally, IGF-1 and IGFBP-3 in the two groups increased significantly 1 month after treatment, but IGF in the high-dose group improved even more significantly although there was a time gap between the two groups.

Clinical studies have indicated that when using rhGH for the treatment of children with type 1 diabetes, the standardized incidence ratio (SIR) was 0.92 [95\% confidence interval (CI), 0.66-1.42] (22-24). Children's glucose homeostasis depends on the balance between glucose utilization and generation of hepatic glucose. The addition of exogenous rhGH may stimulate gluconeogenesis enzymes and reduce the production and inhibition of insulin on glucose. At the same time, rhGH may also reduce the utilization of peripheral sugar, inhibit the activity of insulin (INS)-induced phospholipase C (PLC) activity and interfere with the promotion of INS to sugar metabolism. However, in the present study we were unable to examine the specific mechanism of $\mathrm{rhGH}$ on glucose metabolism in detail. Nonetheless, it has been previously reported that rhGH causes impaired glucose tolerance and insulin sensitivity (25). Deepak et al (26) suggested that after 1 week of treatment with rhGH, FBG levels were markedly changed. After 3 months of treatment, however, the degree of change was retarded. Eugster et al (27) also found that, in a study of 103 adult patients with GHD, continuous supplementation of rhGH after 6 months significantly increased FBG levels, and three patients had transient hyperglycemia. Altomare et al (28) found in a study of 21 children with GHD, with normal glucose tolerance, that the blood glucose AUC increased 6 months after treatment, the glucose tolerance curved downwards, but impaired glucose tolerance or diabetes had not yet become evident. In the present study, we showed that FBG increased in the two groups 3 months after treatment, but the increase in the high-dose group was greater, indicating that insulin resistance induced by high doses of rhGH was more significant.

Due to the growth disorder in children with GHD, the level of thyroid hormone needed for growth was relatively low. Sohmiya and Kato (29) reported that serum T3 levels in patients with idiopathic GHD were decreased, whereas T4 levels increased. Cohen et al (30) also found that the FT3 1 month after treatment in GHD patients was increased and the difference was statistically significant, but 6 months after treatment the difference was not statistically significant. Møller and Jørgensen (31) also believed that during the course of treatment, the changes of FT3, FT4 had a linear correlation with HV. Additionally, thyroid hormone directly promotes the synthesis of IGFBP-2 and IGFBP-4, increases IGF-1 binding capacity, prolongs the half-life of IGF-1 and promotes the growth and development of children. Some investigators have suggested that $\mathrm{GH}$ promoted the secretion of somatostatin, which further inhibited the secretion of TSH and led to changes in thyroid hormone release (32-34). The present study found that thyroid hormone levels in the two groups changed, but they changed more significantly in the 
high-dose group. Furthermore, 6 months after treatment, the difference in T3 levels in the two groups was statistically significant $(\mathrm{P}<0.05)$. High doses of rhGH had a greater impact on thyroid function, and the possibility of adverse reactions cannot be excluded.

In this study, we examined the effects of different doses of rhGH on children with GHD, as well as the changes in the thyroid and glycometabolism. Previously, the high dose of rhGH was thought to have a greater effect on linear growth catch-up and treatment. At the same time, however, high doses of rhGH also increased the incidence of abnormalities in glucose metabolism and thyroid. Since the present study was performed over a relatively short period of time, obvious signs of high blood sugar syndrome and hyperglycemic hyperosmolar syndrome did not manifest in patients. Thus, we hypothesize that high doses of rhGH may have a greater impact on glucose metabolism and thyroid functions and cause a higher risk of function changes. Thus, in future studies attention should be paid to the indicators of glucose metabolism and thyroid function.

\section{References}

1. Austin DE, Gunn AJ and Jefferies CA: Severe short stature and Wolf-Hirschhorn syndrome: response to growth hormone in two cases without growth hormone deficiency. Oxf Med Case Rep 2015: 211-214, 2015.

2. Valença EH, Salvatori R, Souza AH, Oliveira-Neto LA, Oliveira AH, Gonçalves MI, Oliveira CR, D'Ávila JS, Melo VA, de Carvalho S, et al: Voice formants in individuals with congenital, isolated, lifetime growth hormone deficiency. J Voice: pii: S0892-1997(15)00057-0, 2015 (Epub ahead of print).

3. Netchine I, Talon P, Dastot F, Vitaux F, Goossens M and Amselem S: Extensive phenotypic analysis of a family with growth hormone $(\mathrm{GH})$ deficiency caused by a mutation in the GH-releasing hormone receptor gene. J Clin Endocrinol Metab 83: 432-436, 1998.

4. Bao XL, Shi YF, Du YC, Liu R, Deng JY and Gao SM: Prevalence of growth hormone deficiency of children in Beijing. Chin Med J (Engl) 105: 401-405, 1992.

5. Blethen SL, Allen DB and Graves D: Safety of recombinantdeoxyribonucleic acid-derived growth hormone: The National Cooperative Growth Study experience. J Clin Endocrinol Metab 81: 1704-1710, 1996.

6. Frindik JP and Baptista J: Adult height in growth hormone deficiency: historical perspective and examples from the national cooperative growth study. Pediatrics 104: 1000-1004, 1999.

7. Root AW, Kemp SF and Rundle AC: Effect of long-term recombinant growth hormone therapy in children - the National Cooperative Growth Study. J Pediatr Endocrinol Metab 11: 403-412, 1998

8. Famini P, Maya MM and Melmed S: Pituitary magnetic resonance imaging for sellar and parasellar masses: Ten-year experience in 2598 patients. J Clin Endocrinol Metab 96: 1633-1641, 2011.

9. Obara-Moszyńska $M$ and Niedziela M: The usefulness of the GHRH stimulation test in the diagnostics of growth hormone deficiency in children. Endokrynol Pol 66: 137-141, 2015.

10. de Paula FJ, Góis-Júnior MB, Aguiar-Oliveira MH, Pereira Fde A, Oliveira CR, Pereira RM, Farias CT, Vicente TA and Salvatori R: Consequences of lifetime isolated growth hormone (GH) deficiency and effects of short-term GH treatment on bone in adults with a mutation in the GHRH-receptor gene. J Clin Endocrinol (Oxf) 70: 35-44, 2009.

11. Alcântara MR, Salvatori R, Alcântara PR, Nóbrega LM, Campos VS, Oliveira EC, Oliveira MH, Souza AH and AguiarOliveira MH: Thyroid morphology and function in children with untreated isolated growth hormone deficiency. J Clin Endocrinol Metab 91: 364-371, 2013

12. Tanner JM, Whitehouse RH and Takaishi M: Standards from birth to maturity for height, weight, height velocity, and weight velocity: British children, 1965. I. Arch Dis Child 41: 454-471, 1966.
13. Oliveira JL, Aguiar-Oliveira MH, D'Oliveira A Jr, Pereira RM, Oliveira CR, Farias CT, Barreto-Filho JA, Anjos-Andrade FD, Marques-Santos C, Nascimento-Junior AC, et al: Congenital growth hormone $(\mathrm{GH})$ deficiency and atherosclerosis: effects of GH replacement in GH-naive adults. J Clin Endocrinol Metab 92: 4664-4670, 2007.

14. Deal C L, Tony M, Höybye C, David B. Allen, Maïthé Tauber and Jens Christiansen JB: Growth Hormone Research Society Workshop Summary: Consensus Guidelines for Recombinant Human Growth Hormone Therapy in Prader-Willi Syndrome. J Clin Endocrinol Metab 98: E1072-E1087, 2013.

15. Kalina-Faska B, Kalina M and Koehler B: Effects of recombinant growth hormone therapy on thyroid hormone concentrations. Int J Clin Pharmacol Ther 42: 30-34, 2004.

16. Growth Hormone Research Society: Consensus guidelines for the diagnosis and treatment of growth hormone $(\mathrm{GH})$ deficiency in childhood and adolescence: summary statement of the GH Research Society. GH Research Society. J Clin Endocrinol Metab 85: 3990-3993, 2000.

17. Ranke MB, Lindberg A, Price DA, Darendeliler F, AlbertssonWikland K, Wilton P and Reiter EO; KIGS International Board: Age at growth hormone therapy start and first-year responsiveness to growth hormone are major determinants of height outcome in idiopathic short stature. Horm Res 68: 53-62, 2007.

18. Kawa MP, Stecewicz I, Piecyk K, Pius-Sadowska E, Paczkowska E, Rogińska D, Sobuś A, Łuczkowska K, Gawrych E, Petriczko E, et al: Effects of growth hormone therapeutic supplementation on hematopoietic stem/progenitor cells in children with growth hormone deficiency: focus on proliferation and differentiation capabilities. Endocrine: Apr 29, 2015 (Epub ahead of print).

19. Chaplin JE, Kriström B, Jonsson B, Tuvemo T and AlbertssonWikland K: Growth hormone treatment improves cognitive function in short children with growth hormone deficiency. Horm Res Paediatr: Mar 25, 2015 (Epub ahead of print).

20. Davis NL, Stewart CE, Moss AD, Woltersdorf WW, Hunt LP, Elson RA, Cornish JM, Stevens MC and Crowne EC: Growth hormone deficiency after childhood bone marrow transplantation with total body irradiation: interaction with adiposity and age. Clin Endocrinol (Oxf): Mar 21, 2015 (Epub ahead of print).

21. Rose SR, Municchi G, Barnes KM, Kamp GA, Uriarte MM, Ross JL, Cassorla F and Cutler GB Jr: Spontaneous growth hormone secretion increases during puberty in normal girls and boys. J Clin Endocrinol Metab 73: 428-435, 1991.

22. Sverrisdóttir YB1, Elam M, Caidahl K, Söderling AS, Herlitz H and Johannsson G: The effect of growth hormone $(\mathrm{GH})$ replacement therapy on sympathetic nerve hyperactivity in hypopituitary adults: a double-blind, placebo-controlled, crossover, short-term trial followed by long-term open GH replacement in hypopituitary adults. J Hypertens 21: 1905-1914, 2003.

23. Poyrazoğlu Ş, Akçay T, Arslanoğlu İ, Atabek ME, Atay Z, Berberoğlu M, Bereket A, Bideci A, Bircan İ, Böber E, et al: Current practice in diagnosis and treatment of growth hormone deficiency in childhood: A survey from Turkey. J Clin Res Pediatr Endocrinol 7: 37-44, 2015.

24. Tornese G, Marzuillo P, Pellegrin MC, Germani C, Faleschini E, Zennaro F, Grandone A, Miraglia Del Giudice E, Perrone L and Ventura A: A case of Rubinstein-Taybi syndrome associated with growth hormone deficiency in childhood. Clin Endocrinol (Oxf): Feb 14, 2015 (Epub ahead of print).

25. Bramnert M, Segerlantz M, Laurila E, Daugaard JR, Manhem P and Groop L: Growth hormone replacement therapy induces insulin resistance by activating the glucose-fatty acid cycle. J Clin Endocrinol Metab 88: 1455-1463, 2003.

26. Deepak D, Daousi C, Javadpour M, Clark D, Perry Y, Pinkney J and Macfarlane IA: The influence of growth hormone replacement on peripheral inflammatory and cardiovascular risk markers in adults with severe growth hormone deficiency. Growth Horm IGF Res 20: 220-225, 2010.

27. Eugster EA, Fisch M, Walvoord EC, DiMeglio LA and Pescovitz OH: Low hemoglobin levels in children with in idiopathic growth hormone deficiency. Endocrine 18: 135-136, 2002.

28. Altomare F, Rubino M and Matarazzo P: Correlation between IGF-1 serum level and hemoglobin concentration in children with idiopathic growth hormone deficiency (IGHD). J Pediatr 11: 885-889, 2012.

29. Sohmiya M and Kato Y: Effect long-term treatment with recombinant human growth hormone on erythropoietin secretion in an anemic patient with panhypopituitarism. J Endocrinol Invest 36: 331-336, 2010. 
30. Cohen P1, Germak J, Rogol AD, Weng W, Kappelgaard AM and Rosenfeld RG; American Norditropin Study Group: Variable degree of growth hormone $(\mathrm{GH})$ and insulin-like growth factor(IGF) sensitivity in children with idiopathic short stature compared with GH-deficient patients: evidence from an IGF-based dosing study of short children. J Clin Endocrinol Metab 95: 2089-2098, 2010.

31. Møller N and Jørgensen JO: Effects of growth hormone on glucose, lipid, and protein metabolism in human subjects. Endocr Rev 30: 152-177, 2009.

32. Child CJ, Zimmermann AG, Scott RS, Cutler GB Jr, Battelino T and Blum WF; GeNeSIS International Advisory Board: Prevalence and incidence of diabetes mellitus in GH-treated children and adolescents: analysis from the GeNeSIS observational research program. J Clin Endocrinol Metab 96: E1025-E1034, 2011.
33. Mauras N1, Attie KM, Reiter EO, Saenger P and Baptista J: High dose recombinant human growth hormone $(\mathrm{GH})$ treatment of GH-deficient patients in puberty increases hear-final height: a randomized, multicenter trial. J Clin Endocrinol Metab 85: 3653-3660, 2010.

34. Coelho R, Brook CG, Preece MA, Stanhope RG, Dattani MT and Hindmarsh PC: A randomised study of two doses of biosynthetic human growth hormone on final height of pubertal children with growth hormone deficiency. Horm Res 70: 85-88, 2008. 